\author{
DOMINIKA CENDROWICZ \\ ORCID: 0000-0002-2358-7188 \\ Uniwersytet Wrocławski \\ dominika.cendrowicz@uwr.edu.pl
}

\title{
O niepomijalnej roli gminy w obszarze zadań administracji świadczącej
}

\begin{abstract}
Abstrakt: Celem artykułu jest analiza roli gminy w obszarze zadań administracji świadczącej. Gmina, będąca podstawową jednostką samorządu terytorialnego, realizuje liczne zadania z zakresu administracji świadczącej. Są to zadania o znaczeniu lokalnym i publicznym, które z punktu widzenia obywateli są często o wiele ważniejsze niż sprawy wagi państwowej. Wynika to z istoty zadań administracji świadczącej.
\end{abstract}

Słowa kluczowe: administracja publiczna, niepomijalność, samorząd terytorialny, gmina, administracja świadcząca.

\section{Uwagi wprowadzające}

Tematyka niepomijalności administracji publicznej przyjęta jako motyw przewodni ogólnopolskiej konferencji naukowej zorganizowanej dla uczczenia rocznicy pięćdziesięciolecia utworzenia Instytutu Nauk Administracyjnych Uniwersytetu Wrocławskiego jest kontynuacją i nawiązaniem do dorobku wrocławskiej szkoły administratywistów w zakresie badań nad administracją publiczną. Przedstawiciele tej szkoły w swoich badaniach nad administracją publiczną eksponowali jej służebną rolę wobec człowieka, któremu powinna ona służyć, a za rację jej bytu uznawali zadania publiczne. Na te dwie cechy kładziono więc nacisk w tworzonych we wrocławskim ośrodku naukowym definicjach administracji publicznej pomimo zmieniających się warunków polityczno-prawnych, w których nieraz z trudem przychodziło jej funkcjonować w Polsce po 1945 roku. Wśród powstałych na Uniwersytecie Wrocławskim definicji administracji publicznej, 
które wpisały się w ten nurt badawczy, warto chociażby wskazać na tę autorstwa T. Bigi. Wyrażał on bowiem zdanie, że administracja publiczna oznacza planową działalność państwa zmierzającą do realizacji pewnych celów, która nie jest ustawodawstwem ani sądownictwem, ma na celu dobro wspólne, interes publiczny i jest oparta na przepisach prawa ${ }^{1}$. O administracji pisali we Wrocławiu także F. Longchamps, zwracający uwagę, że jest ona zjawiskiem społecznym, które cechuje inicjatywa i działalność ukierunkowana na przyszłość ${ }^{2}$, oraz T. Kuta. Ten drugi w warunkach ustroju państwa socjalistycznego definiował administrację państwową (publiczną) jako „swoiste zjawisko państwowo-polityczno-prawne rozumiane jako planowa, celowo zorganizowana działalność organów państwowych polegająca na bezpośrednim organizowaniu praktycznej realizacji zadań państwa"3. Podobnie, ale już w warunkach ustroju państwa demokratycznego, definiował administrację publiczną J. Boć, pisząc, że oznacza ona „przejęte przez państwo i realizowane przez jego zawisłe organy, a także przez organy samorządu terytorialnego zaspokajanie zbiorowych i indywidualnych potrzeb obywateli, wynikających ze współżycia ludzi w społeczeństwie"4. W przedstawionych definicjach administracji publicznej przebija się nie tylko racja jej bytu, a więc zadania publiczne, ale i sens humanistyczny nauki prawa administracyjnego, tak podkreślany w pracach $\mathrm{F}$. Longchampsa, zgodnie $\mathrm{z}$ którym wszelkim działaniom podejmowanym przez administrację ma przyświecać człowiek. On to jest bowiem ostatecznym celem jej działań. To jemu administracja powinna służyć.

\section{Przesłanki aksjologiczne realizacji przez gminę zadań w obszarze administracji świadczącej}

Jednym z podstawowych kierunków działania tak definiowanej administracji publicznej jest administracja świadcząca, której ważnym podmiotem pozostaje samorząd terytorialny. W obrębie samorządu terytorialnego to zwłaszcza gmina jest postrzegana jako główny podmiot zaspokajania podstawowych potrzeb człowieka w ramach administracji świadczącej ${ }^{5}$. Do aksjologicznych przesłanek realizacji przez gminę znacznej liczby zadań w obszarze administracji świadczącej należą zasady pomocniczości oraz decentralizacji. Pierwsza z nich wywodzi się

1 T. Bigo, Prawo administracyjne. Instytucje ogólne, Wrocław 1948, s. 15.

2 F. Longchamps, W sprawie pojęcia administracji państwowej i pojęcia prawa administracyjnego, „Zeszyty Naukowe Uniwersytetu Wrocławskiego” 1958, seria A, nr 10, s. 21.

3 T. Kuta, [w:] Prawo administracyjne. Zagadnienia podstawowe, red. J. Boć, T. Kuta, Warszawa 1984, s. 10.

4 J. Boć, [w:] Prawo administracyjne, red. J. Boć, Wrocław 2010, s. 15.

5 I. Lipowicz, Samorzad terytorialny jako podmiot administracji świadczacej, „Ruch Prawniczy, Ekonomiczny i Socjologiczny" 77, 2015, nr 3, s. 115. 
z idei subsydiarności. W prawie krajowym wyraża ją przede wszystkim preambuła do Konstytucji Rzeczypospolitej Polskiej z dnia 2 kwietnia 1997 roku $^{6}$. Treści nią inspirowane można odnaleźć jednak także w innych przepisach Konstytucji

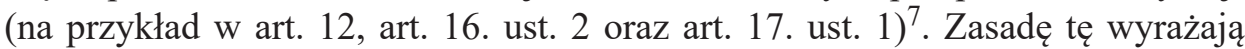
również art. 5 ust. 3 Traktatu o Unii Europejskiej ${ }^{8}$ i art. 4 ust. 3 Europejskiej Karty Samorządu Lokalnego9. Przywołana zasada zakłada w jednym ze swoich aspektów podział zadań między państwo a samorząd terytorialny, zgodnie z którym to samorząd realizuje sprawy o znaczeniu lokalnym. Zasada ta określa także zakres wolności obywatelskich w sposób gwarantujący jak najszerszą autonomię obywateli oraz mniejszych wspólnot ${ }^{10}$. Zdaniem M. Kuleszy, stosując zasadę pomocniczości, należy mieć na uwadze konsekwencje, jakie powoduje ${ }^{11}$, ponieważ — jak wskazał Trybunał Konstytucyjny w wyroku z dnia 7 grudnia 2005 roku nie zawsze jest to optymalna zasada dokonywania podziałów zadań i kompetencji w ramach administracji publicznej ${ }^{12}$.

Natomiast jeśli chodzi o zasadę decentralizacji, to w prawie krajowym wyraża ją art. 15 ust. 1 Konstytucji. Zawarta w tym przepisie zasada decentralizacji, mimo że jest jedną z zasad samorządu terytorialnego, zdaniem Trybunału Konstytucyjnego, przedstawionym w wyroku z dnia 4 maja 1998 roku, powinna być odnoszona do organizacji i ustroju całego państwa, a nie wyłącznie do samorządu terytorialnego ${ }^{13}$. W dalszej kolejności należy wskazać, że Trybunał Konstytucyjny, wyjaśniając istotę omawianej zasady w odniesieniu do samorządu terytorialnego, zauważył, że oznacza ona

taki sposób organizacji aparatu wykonawczego w państwie, w którym jednostki terytorialne lub inne mają samodzielność określoną ustawą, a ingerencja w zakres tej samodzielności może odbywać się tylko na podstawie ustawy i w formach nią przewidzianych, z których podstawową pozostaje nadzór weryfikacyjny oparty na kryterium zgodności z prawem ${ }^{14}$.

${ }^{6}$ Konstytucja Rzeczypospolitej Polskiej z dnia 2 kwietnia 1997 roku (Dz.U. Nr 78, poz. 483 z późn. zm.).

7 E. Popławska, Zasada pomocniczości (subsydiarności), [w:] Zasady podstawowe polskiej konstytucji, red. W. Sokolewicz, Warszawa 1998, s. 198.

8 Traktat o Unii Europejskiej (wersja skonsolidowana) (Dz.Urz. UE C 326/15 z 26.10.2012).

9 Europejska Karta Samorządu Lokalnego, sporządzona w Strasburgu dnia 15 października 1985 roku (Dz.U. z 1994 r. Nr 124, poz. 607; dalej: EKSL).

10 M. Radwan-Röhrenschef, Zasada subsydiarności w polityce regionalnej Wspólnoty Europejskiej, [w:] Subsydiarność, red. D. Milczarek, Warszawa 1998, s. 209.

${ }^{11}$ M. Kulesza, Zasada subsydiarności jako klucz do reformy ustroju administracyjnego państw Europy Środkowej i Wschodniej (na przykładzie Polski), [w:] Subsydiarność, red. D. Milczarek, Warszawa 1998, s. 119-120.

12 Wyrok Trybunału Konstytucyjnego z dnia 7 grudnia 2005 roku, sygn. Kp 3/05, OTK ZU 2005, Nr 10, poz. 115, seria A.

13 Wyrok Trybunału Konstytucyjnego z dnia 4 maja 1998 roku, sygn. K 38/97, OTK ZU 1998, $\mathrm{Nr} 3$, poz. 31.

14 Wyrok Trybunału Konstytucyjnego z dnia 25 listopada 2002 roku, sygn. K 34/01, OTK ZU 2002, Nr 6A, poz. 84. 
Należy również zwrócić uwagę, że także z zasady decentralizacji wynika „przekazywanie z góry w dół” zadań publicznych na niższe ogniwa ich wykonywania ${ }^{15}$. Powoduje to, że omówione zasady — pomocniczości i decentralizacji — pozostają z sobą w bezpośrednim związku.

\section{Gmina jako niepomijalny element administracji publicznej}

Gmina, w stosunku do której istnieją w prawie aksjologiczne przesłanki realizacji przez nią zadań w obszarze administracji świadczącej, jest podstawową jednostką samorządu terytorialnego (art. 164 ust. 1 Konstytucji). To właśnie uczynienie przez prawodawcę z gminy podstawowej jednostki samorządu terytorialnego przesądza o jej pozycji w systemie zadań administracji świadczącej. Należy bowiem podkreślić, że samorząd terytorialny tworzy nie tylko jeden $\mathrm{z}$ fundamentów demokratyzacji życia społecznego ${ }^{16}$, lecz także formę decentralizacji administracji publicznej ${ }^{17}$ i przejaw zasady pomocniczości w życiu publicznym. Jego istnienie jest ,wynikiem instynktu samozachowawczego, przy pewnym rozwoju, którego człowiek chce stanowić o sobie, a o kwestiach dotyczących jego i sąsiadów, wraz z tymi ostatnimi" 18 . Podmiotem samorządu terytorialnego jest społeczność zamieszkująca dane terytorium. Tworzy ją wspólnota samorządowa zorganizowana w związek o charakterze terytorialno-samorządowym. Przedmiotem zaś samorządu terytorialnego jest realizacja zadań publicznych ${ }^{19}$. Samorząd terytorialny wykonuje zadania publiczne niezastrzeżone przez Konstytucję lub ustawy dla organów innych władz publicznych (art. 163 Konstytucji).

W Polsce funkcjonuje trójstopniowa struktura samorządu terytorialnego. Składają się na nią gminy, powiaty i województwa. Jak już była mowa, podstawową jednostką samorządu terytorialnego jest właśnie gmina, którą w świetle art. 1 ust. 1 ustawy z dnia 8 marca 1990 roku o samorządzie gminnym ${ }^{20}$ tworzy upodmiotowiona wspólnota lokalna oraz odpowiednie terytorium ${ }^{21}$. Gmina

15 K. Kokocińska, Decentralizacja jako ustrojowa zasada relacji pomiędzy organami władzy publicznej, „Ruch Prawniczy, Ekonomiczny i Socjologiczny” 78, 2016, nr 2, s. 28.

16 J. Jeżewski, Idea demokracji w przekształceniach samorzadu terytorialnego, „,Ruch Prawniczy, Ekonomiczny i Socjologiczny" 77, 2015, nr 3, s. 77.

17 T. Bigo, Związki publiczno-prawne w świetle ustawodawstwa polskiego, Warszawa 1928, s. $55,152 \mathrm{n}$.

18 A. Kroński, Teorja samorządu terytorialnego, Warszawa 1932, s. 22.

19 B. Dolnicki, Samorzad terytorialny, Warszawa 2016, s. 24, 27.

20 Ustawa z dnia 8 marca 1990 roku o samorządzie gminnym (tekst jedn. Dz.U. z 2020 r. poz. 713; dalej: u.s.g.).

21 A. Doliwa, Osobowość prawna jednostek samorzadu terytorialnego, Warszawa 2012, s. 45. 
jest podstawowym ogniwem samorządu terytorialnego ${ }^{22}$. Znajduje się najbliżej społeczności lokalnej i jej problemów. To właśnie ta cecha gminy przekłada się na zakres realizowanych przez nią zadan, ich przedmiot oraz znaczenie dla społeczności lokalnej, która zamieszkuje jej terytorium. Założenie to znajduje wyraz w art. 164 ust. 3 Konstytucji wyrażającym domniemanie zadań gminy w obrębie samorządu terytorialnego. Przepis ten stanowi, że „Gmina wykonuje wszystkie zadania samorządu terytorialnego niezastrzeżone dla innych jednostek samorządu terytorialnego". Konstytucyjne domniemanie zadań gminy znajduje rozwinięcie $\mathrm{w}$ treści art. 6 ust. 1 u.s.g. w zw. z art. 7 ust. 1 u.s.g. Ustawa o samorządzie gminnym ogranicza jednak zakres domniemania zadań gminy do spraw publicznych o znaczeniu lokalnym, przede wszystkim do zaspokajania zbiorowych potrzeb wspólnoty gminnej ${ }^{23}$. Zarówno konstytucyjna, jak i ustawowa regulacja zadań gminy pozostają $\mathrm{w}$ związku z art. 4 ust. 1 EKSL.

W dalszej kolejności należy wskazać, że z art. 166 ust. 1 Konstytucji wynika, że wszystkie jednostki samorządu terytorialnego, wykonując zadania służące zaspokajaniu potrzeb wspólnoty samorządowej, realizują je jako zadania własne. W odniesieniu natomiast do gminy przepis art. 7 ust. 1 u.s.g. stanowi, że zaspokajanie zbiorowych potrzeb wspólnoty samorządowej należy do zadań własnych tej jednostki samorządu terytorialnego ${ }^{24}$. Zadania te obejmują w szczególności sprawy z zakresu ładu przestrzennego, gospodarki nieruchomościami, gospodarki wodnej, gminnych dróg, ulic, mostów, placów, wodociągów i zaopatrzenia w wodę, kanalizacji, utrzymania czystości i porządku oraz urządzeń sanitarnych, lokalnego transportu zbiorowego, ochrony zdrowia, pomocy społecznej, gminnego budownictwa mieszkaniowego oraz edukacji publicznej. Wymienione w tym przepisie sprawy, którymi w głównej mierze powinna zajmować się gmina, mają nie tylko publiczny, ale równocześnie lokalny charakter ${ }^{25}$. Tworzą one ponadto otwarty katalog zadań gminy. Ustawy określają, które zadania własne gminy mają charakter obowiązkowy (art. 7 ust. 2 u.s.g.).

22 A. Skoczylas, W. Piątek, Komentarz do art. 188, [w:] Konstytucja RP. Komentarz, t. 2, red. M. Safjan, L. Bosek, Warszawa 2016, s. 888.

${ }^{23}$ H. Izdebski, Domniemanie zadań samorządu terytorialnego i domniemanie zadań gminy w obrębie samorzadu terytorialnego - klauzule generalne dotyczace zadań samorzadu terytorialnego, „Samorząd Terytorialny” 2015, nr 1-2, s. 70.

24 T. Moll, [w:] Ustawa o samorzadzie gminnym. Komentarz, red. B. Dolnicki, Warszawa 2016, s. 214.

25 J. Korczak, Ewolucja gminy jako podstawowej jednostki samorzadu terytorialnego, [w:] Studia nad samorzadem terytorialnym, red. A. Błaś, Wrocław 2002, s. 89. 


\section{Administracja świadcząca jako niepomijalna funkcja administracji publicznej}

W obszarze zadań własnych gminy, o których mowa w art. 7 ust. 1 u.s.g., znajdują się liczne zadania $\mathrm{z}$ zakresu administracji świadczącej. Z punktu widzenia jednostki - obywatela są one jednymi z ważniejszych zadań, które zostały przypisane do realizacji gminie. Ludzie od zawsze zgłaszali zapotrzebowanie na usługi administracji świadczącej ${ }^{26}$. Administracja świadcząca jest bowiem jedną z funkcji administracji publicznej, oznaczającą działalność tej administracji, polegającą na bezpośrednim zaspokajaniu potrzeb jednostek za pomocą dóbr zarówno materialnych, jak i niematerialnych ${ }^{27}$. Definiuje się ją także jako działalność realizującą zadania społecznie użyteczne. Administracja świadcząca koncentruje się na utrzymaniu lub poprawie warunków bytowych poprzez dostarczanie (organizację dostarczania) świadczeń ${ }^{28}$.

Do jej istotnych cech zalicza się to, że adresatem jej działań jest człowiek, a jej celem — świadczenie usług zaspokajających jego indywidualne oraz zbiorowe interesy, jak również to, że charakteryzuje się ona równością i ogólnym dostępem do świadczonych przez nią usług, a część jej zadań może być powierzana do realizacji podmiotom niepublicznym, takim jak organizacje pozarządowe. Do jej społecznie ważnych obszarów należą: pomoc społeczna, edukacja publiczna, ochrona zdrowia, wodociągi, transport lokalny itp. Charakterystyczną dla administracji świadczącej formą organizacyjnoprawną świadczonych przez nią usług jest zakład administracyjny oraz przedsiębiorstwo. Administracja świadcząca jest jedną z bardziej dynamicznych funkcji administracji publicznej ${ }^{29}$. Tę jej cechę obrazuje przede wszystkim to, że w ciągu lat sfera jej zadań znacznie się rozszerzyła, a niektóre obszary jej działalności uległy dywersyfikacji ${ }^{30}$. Tym, co w odniesieniu do administracji świadczącej pozostaje niezmienne, jest to, że istotną rolę w realizacji zadań z jej zakresu odgrywa samorząd terytorialny, zwłaszcza gmina, której rola jest wiodąca, jeśli chodzi o realizację zadań administracji świadczącej o lokalnym znaczeniu ${ }^{31}$.

26 J. Posłuszny, Istota i cechy administracji świadczacej, „Administracja. Teoria — Dydaktyka - Praktyka” 2005, nr 1, s. 62-66.

27 P. Chmielnicki, Świadczenie ustug przez samorzad terytorialny w Polsce. Studium ustrojowoprawne, Warszawa 2002, s. 36.

28 I. Sierpowska, Pomoc społeczna jako administracja świadczaca, Warszawa 2012, s. 117.

29 J. Posłuszny, op. cit., s. 62-66.

30 Szerzej zob. T. Kuta, Aspekty prawne w organizowaniu ustug, Wrocław 1969; I. Lipowicz, Pojęcie administracji świadczacej w doktrynie zachodnioniemieckiej, [w:] Regulacja prawna administracji świadczacej, red. K. Podgórski, Katowice 1985.

31 Zob. I. Lipowicz, Samorząd terytorialny..., s. 115. 


\section{Zadania gminy w obszarze administracji świadczącej}

To, że gmina realizuje znaczną część zadań administracji świadczącej, wynika $\mathrm{z}$ tego, że w odniesieniu do tej jednostki samorządu terytorialnego przyjęta została najszersza formuła zadaniowa tworząca fundament jej władztwa kompetencyjnego $^{32}$. To także wyraz zasady pomocniczości. Określony w art. 7 ust. 1 u.s.g. katalog spraw, którymi powinna zajmować się gmina, wskazuje na liczne obowiązki tej jednostki samorządu terytorialnego w obszarze administracji świadczącej. Do ważniejszych zadań gminy w obszarze administracji świadczącej w świetle tego przepisu należą sprawy z zakresu pomocy społecznej, wspierania rodziny i systemu pieczy zastępczej, ochrony zdrowia, edukacji publicznej, kultury, gminnego budownictwa mieszkaniowego, zaopatrzenia w wodę i usuwania ścieków, utrzymania czystości i porządku, usuwania odpadów, a także transportu lokalnego ${ }^{33}$. Nałożone na gminę tym przepisem obowiązki w zakresie administracji świadczącej należy oceniać w powiązaniu z przepisami ustaw szczególnych. To one bowiem uszczegóławiają, które zadania gmina powinna realizować w określonym obszarze administracji świadczącej, dokonują ich dywersyfikacji na zadania własne obowiązkowe i fakultatywne oraz stanowią, czy gmina realizuje zadania zlecone z zakresu administracji rządowej w danym obszarze administracji świadczącej. Tak jest na przykład w wypadku pomocy społecznej, przy której wynikający z treści art. 7 ust. 1 pkt 6 u.s.g. obowiązek realizacji przez gminę zadań z tego zakresu należy oceniać w powiązaniu z przepisami ustawy z dnia 12 marca 2004 roku o pomocy społecznej ${ }^{34}$. Ustawa ta precyzuje w art. 17 i 18 , że gmina wykonuje w pomocy społecznej nie tylko zadania własne obowiązkowe i zadania własne fakultatywne, lecz także zadania zlecone z zakresu administracji rządowej ${ }^{35}$. Wynikające $\mathrm{z}$ tych przepisów zadania, które gmina realizuje w ramach pomocy społecznej, obejmują rozbudowany katalog spraw. Do zadań własnych obowiązkowych, własnych fakultatywnych oraz zleconych gminie z zakresu administracji rządowej w świetle art. 17 i 18 u.p.s. należy przykładowo udzielanie schronienia, zapewnienie posiłku oraz niezbędnego ubrania osobom tego pozbawionym, przyznawanie i wypłacanie licznych zasiłków pieniężnych (na przykład zasiłków stałych i okresowych), świadczenie pracy socjalnej, udzielanie pomocy na ekonomiczne usamodzielnienie oraz sporządzanie oceny zasobów pomocy społecznej

32 J. Korczak, op. cit., s. 89.

33 Por. P. Chmielnicki, op. cit., s. 38-60.

34 Ustawa z dnia 12 marca 2004 roku o pomocy społecznej (Dz.U. z 2019 r. poz. 1507 z późn. zm.; dalej: u.p.s.).

35 Wyrok Wojewódzkiego Sądu Administracyjnego w Olsztynie z dnia 25 lutego 2009 roku, sygn. I SA/O1 11/09, CBOSA. 
na podstawie analizy lokalnej sytuacji społecznej i demograficznej gminy w zakresie pomocy społecznej.

Analogicznie sytuacja przedstawia się z zadaniami gminy w zakresie ochrony zdrowia, o których mowa w art. 7 ust. 1 pkt 5 u.s.g. W tym obszarze administracji świadczącej gmina także realizuje rozbudowany katalog zadań publicznych. Przede wszystkim może tworzyć i prowadzić samodzielne publiczne zakłady opieki zdrowotnej $^{36}$, jak również odpowiada za prowadzenie działań związanych z profilaktyką i rozwiązywaniem problemów alkoholowych ${ }^{37}$. W obszarze omawianych zadań gminy mieszczą się ponadto zadania w zakresie zapewnienia równego dostępu do świadczeń opieki zdrowotnej. Do zadań własnych gminy w tym zakresie należą przykładowo: opracowywanie, realizacja i ocena efektów programów polityki zdrowotnej wynikających z rozpoznanych potrzeb zdrowotnych i stanu zdrowia mieszkańców gminy oraz inicjowanie i udział w wytyczaniu kierunków przedsięwzięć lokalnych zmierzających do zaznajamiania mieszkańców z czynnikami szkodliwymi dla zdrowia oraz ich skutkami ${ }^{38}$. W sferze ochrony zdrowia publicznego gmina odpowiada także za realizację usług opiekuńczych dla osób z zaburzeniami psychicznymi ${ }^{39}$.

Natomiast katalog spraw gminy w obszarze edukacji publicznej (art. 7 ust. 1 pkt 8 u.s.g.) jest nie tylko rozbudowany i obejmuje w ramach obowiązkowych zadań własnych między innymi zakładanie i prowadzenie publicznych przedszkoli $^{40}$, ale podlega również ewolucji, która jest rezultatem zmian zachodzących w prawie oświatowym ${ }^{41}$. Wynikiem jego modyfikacji jest chociażby likwidacja obowiązkowego zadania własnego gminy w postaci zakładania i prowadzenia gimnazjów ${ }^{42}$. Zmienność zadań gminy na przykładzie zadań w zakresie edukacji publicznej potwierdza, że administracja świadcząca, jak żadna inna funkcja administracji publicznej, reaguje na zmieniającą się rzeczywistość, a zakres jej zadań, nawet jeśli jest określony w prawie, nie jest stały i ustanowiony raz na zawsze ${ }^{43}$.

${ }^{36}$ Zob. art. 47 ustawy z dnia 13 października 1998 roku - Przepisy wprowadzające ustawy reformujące administrację publiczną (Dz.U. Nr 133, poz. 872 z późn. zm.) oraz art. 50a-82 ustawy z dnia 15 kwietnia 2011 roku o działalności leczniczej (Dz.U. z 2018 r. poz. 2190 z późn. zm.).

37 Zob. art. 4 ust. 1 ustawy z dnia 26 października 1982 roku o wychowaniu w trzeźwości i przeciwdziałaniu alkoholizmowi (Dz.U. z 2018 r. poz. 2137 z późn. zm.).

38 Zob. art. 7 ust. 1 ustawy z dnia 27 sierpnia 2004 roku o świadczeniach opieki zdrowotnej finansowanych ze środków publicznych (Dz.U. z 2019 r. poz. 1373 z późn. zm.).

39 Zob. art. 9 ust. 1 i 4 ustawy z dnia 19 sierpnia 1994 roku o ochronie zdrowia psychicznego (Dz.U. z 2018 r. poz. 1878 z późn. zm.).

40 Art. 8 ust. 15 ustawy z dnia 14 grudnia 2016 roku — Prawo oświatowe (Dz.U. z 2019 r. poz. 1148 z późn. zm.; dalej: pr.ośw.).

41 Ustawami wytyczającymi obecne zadania gminy w edukacji publicznej są ustawa $\mathrm{z}$ dnia 7 września 1991 roku o systemie oświaty (Dz.U. z 2019 r. poz. 148) oraz pr.ośw.

42 Zob. art. 117 ustawy z 14 grudnia 2016 roku - Przepisy wprowadzające ustawę Prawo oświatowe (Dz.U. z 2017 r. poz. 6 z późn. zm.).

43 J. Posłuszny, op. cit., s. 67. 
Wypada także zauważyć, że wiele zadań z obszaru administracji świadczącej gmina realizuje przy wykorzystaniu form organizacyjnoprawnych zakładów administracyjnych, jak szkoły, domy pomocy społecznej o zasięgu gminnym czy na przykład biblioteki. Z niektórych zadań realizowanych przez gminy w obszarze administracji świadczącej korzystają wszyscy jej mieszkańcy (przykładowo zaopatrzenie w wodę, usuwanie odpadów), z niektórych zaś tylko ich część (chociażby edukacja publiczna, kultura). Wiele z tych zadań obejmuje sprawy społeczne, takie jak zapewnienie minimum godnych warunków życiowych, zwalczanie ubóstwa i bezdomności (pomoc społeczna) czy ochronę zdrowia ${ }^{44}$. Ich wspólnym mianownikiem jest to, że są adresowane do człowieka, a ich celem jest zaspokajanie jego potrzeb.

\section{Konkluzja}

Reasumując zawarte $\mathrm{w}$ tekście rozważania, należy ponownie podkreślić, że gmina nieodłącznie odgrywa ważną rolę w systemie samorządu terytorialnego oraz całej administracji publicznej. Jest to jednostka samorządu terytorialnego, do której przypisane zostało domniemanie realizacji zadań o znaczeniu lokalnym i publicznym w obrębie samorządu terytorialnego. Gmina realizuje rozbudowany katalog zadań publicznych, wśród których wyraźnie dają się zauważyć zadania z obszaru administracji świadczącej. Przyjęcie w prawie, że gmina pozostaje istotnym realizatorem zadań administracji świadczącej jest rozwiązaniem znanym $\mathrm{w}$ historii ustawodawstw europejskich ${ }^{45}$. Rozwiązanie to koresponduje $\mathrm{z}$ zasadą pomocniczości będącą obecnie jednym $z$ fundamentów systemu prawa i organizacji administracji publicznej, a także z założeniami zasady decentralizacji. Jest ono dodatkowo następstwem charakteru administracji świadczącej oraz istoty zadań, które w jej ramach realizuje administracja publiczna.

\section{Bibliografia}

Bigo T., Prawo administracyjne. Instytucje ogólne, Wrocław 1948.

Bigo T., Zwiazki publiczno-prawne w świetle ustawodawstwa polskiego, Warszawa 1928.

Boć J., [w:] Prawo administracyjne, red. J. Boć, Wrocław 2010.

Chmielnicki P., Świadczenie usług przez samorzad terytorialny w Polsce. Studium ustrojowoprawne, Warszawa 2002.

Doliwa A., Osobowość prawna jednostek samorządu terytorialnego, Warszawa 2012.

Dolnicki B., Samorzad terytorialny, Warszawa 2016.

44 I. Sierpowska, op. cit., s. 17.

45 I. Lipowicz, Samorzad terytorialny..., s. 115. 
Izdebski H., Domniemanie zadań samorzadu terytorialnego i domniemanie zadań gminy w obrębie samorzadu terytorialnego - klauzule generalne dotyczace zadań samorzadu terytorialnego, „Samorząd Terytorialny” 2015, nr 1-2.

Jeżewski J., Idea demokracji w przekształceniach samorzadu terytorialnego, „Ruch Prawniczy, Ekonomiczny i Socjologiczny" 77, 2015, nr 3.

Kokocińska K., Decentralizacja jako ustrojowa zasada relacji pomiędzy organami władzy publicznej, „Ruch Prawniczy, Ekonomiczny i Socjologiczny” 78, 2016, nr 2.

Korczak J., Ewolucja gminy jako podstawowej jednostki samorzadu terytorialnego, [w:] Studia nad samorzadem terytorialnym, red. A. Błaś, Wrocław 2002.

Kroński A., Teorja samorządu terytorialnego, Warszawa 1932.

Kulesza M., Zasada subsydiarności jako klucz do reformy ustroju administracyjnego państw Europy Środkowej i Wschodniej (na przykładzie Polski), [w:] Subsydiarność, red. D. Milczarek, Warszawa 1998.

Kuta T., [w:] Prawo administracyjne. Zagadnienia podstawowe, red. J. Boć, T. Kuta, Warszawa 1984.

Kuta T., Aspekty prawne w organizowaniu ustug, Wrocław 1969.

Lipowicz I., Pojęcie administracji świadczacej w doktrynie zachodnioniemieckiej, [w:] Regulacja prawna administracji świadczacej, red. K. Podgórski, Katowice 1985.

Lipowicz I., Samorzad terytorialny jako podmiot administracji świadczacej, ,Ruch Prawniczy, Ekonomiczny i Socjologiczny" 77, 2015, nr 3.

Longchamps F., W sprawie pojęcia administracji państwowej i pojęcia prawa administracyjnego, „Zeszyty Naukowe Uniwersytetu Wrocławskiego” 1958, seria A, nr 10.

Moll T., [w:] Ustawa o samorzadzie gminnym. Komentarz, red. B. Dolnicki, Warszawa 2016.

Popławska E., Zasada pomocniczości (subsydiarności), [w:] Zasady podstawowe polskiej konstytucji, red. W. Sokolewicz, Warszawa 1998.

Posłuszny J., Istota i cechy administracji świadczacej, „Administracja. Teoria — Dydaktyka Praktyka" 2005, nr 1 .

Radwan-Röhrenschef M., Zasada subsydiarności w polityce regionalnej Wspólnoty Europejskiej, [w:] Subsydiarność, red. D. Milczarek, Warszawa 1998.

Sierpowska I., Pomoc społeczna jako administracja świadczaca, Warszawa 2012.

Skoczylas A., Piątek W., Komentarz do art. 188, [w:] Konstytucja RP. Komentarz, t. 2, red. M. Safjan, L. Bosek, Warszawa 2016.

\section{On the significant role of the commune in the system of public tasks of administration of provision}

Summary

The aim of the article is to present the role of the commune in the system of public tasks of administration of provision. The commune is the basic unit of local self-government in Poland, the scope of its activities comprises matters of administration of provision. These tasks are of local and public significance and from the citizens' point of view are very often more important than the matters of state. The reason for this is the nature of these public tasks.

Keywords: public administration, unavoidability, local self-government, commune, administration of provision. 